\title{
Indonesian Chinese in the Netherlands and the legacies of violence in colonial and postcolonial Indonesia
}

\author{
Alexander van der MEER AND MARTiJn EICKHOfF
}

\begin{abstract}
After Indonesian independence in 1945, thousands of Indonesian Chinese repatriated to the Netherlands, the former colonizer. As opposed to other repatriates from Indonesia, who organized themselves into pressure groups and fought for a place in the national memory culture, the Indonesian Chinese in the Netherlands only formed strict socio-cultural associations and have generally stayed clear of identity politics. Usually, this divergence is attributed to the smooth integration and socio-economic success of the latter group, as well as to Chinese values, such as conflict avoidance.

This article adds to this explanation by positing that this phenomenon has also been induced by the legacy of anti-Chinese violence in colonial and postcolonial Indonesia: respectively, Dutch discomfort to acknowledge the violent and discriminatory elements of its own colonial history, as well as a fear of offending the Indonesian government. Consequently, many Indonesian Chinese in the Netherlands have engaged in some form of public self-silencing.

KEYWORDS

Indonesian Chinese; postcolonial migrants; national memory culture; selfsilencing.
\end{abstract}

\footnotetext{
ALEXANDER VAN DER MEER, MA (1989) was an intern at the NIOD Institute for War, Holocaust and Genocide Studies. He is studying political history at Radboud Universiteit Nijmegen, and is currently writing a thesis about the Indonesian Chinese in the Netherlands. Alexander van der Meer can be contacted at: vandermeer.aj@gmail.com.
}

DR MARTIJN EICKHOFF (1967) is senior researcher at the NIOD Institute for War, Holocaust and Genocide Studies. His specialism is the historical culture of regime change and mass violence. Martijn Eickhoff can be contacted at: m.eickhoff@niod.knaw.nl. 


\section{INTRODUCTION $^{1}$}

It is a matter for psychologists to analyse why our parents' generation was not afraid to be politically active during colonial rule [in Indonesia], but, now that the colonial power is gone, our generation [in the Netherlands] is afraid to act likewise (Translated from Dutch; Tjwan Sie Hok 2003: 13-14).

According to the sociologist Jolande Withuis, the Dutch public became aware in the early 1970s that many Jewish Holocaust survivors were struggling with historical trauma. As a result of this realization, these survivors became eligible to receive financial compensation and psychological healthcare from state funds. Shortly thereafter, many other groups followed suit and presented themselves as victims of historical injustice as well (Withuis 2002: 8-11, 57-64, 239-241). Amongst these were sexual minorities, Afro-Surinamese descendants of slaves and repatriates from Indonesia. They appealed to the Dutch government and public to acknowledge and compensate their historical suffering in a similar manner. However, as they petitioned for scarce public resources, a certain level of competition became apparent. According to Withuis, "a low point in jealousy between victim groups are the repatriates from Indonesia, who complain time and again that, because they have been 'too civil, clumsy or modest, the Jews go first' and 'receive more' [...]" (Translated from Dutch; Withuis 2002: 239).

Regarding these repatriates, as a result of the Indonesian independence in 1945, up to 300,000 people from the former Dutch East Indies migrated to the Netherlands. Besides smaller groups, such as the Dutch colonial elite and Moluccans who had fought on the Dutch side during the Indonesian war of independence (1945-1949), around $60 \%$ of them were so-called "IndoEuropeans" - of mixed Indonesian and European descent. Obviously, some of these repatriates were soldiers and bureaucrats in the colonial government, whose jobs were invalidated after sovereignty was handed over. However, others left out of fear of violence and discrimination (Oostindie 2010: 26-32).

Many of this diverse group had first suffered during the Japanese occupation of Indonesia (1942-1945), and again during the so-called Bersiap period (1945-1946). On top of that, after arriving in the Netherlands, they often faced a frosty reception from the native Dutch, were housed in poor conditions, and consequently felt unwelcome. To add insult to injury, many of those with a coloured skin reported to have experienced racial discrimination. Since the 1970s, amongst these repatriates - a large part of which became known as "Indisch" -, some have organized themselves into pressure groups, and appealed to the Dutch public and government to be acknowledged and compensated (Oostindie 2010: 33, 73-87, 91-96, 106-114). In some respects,

1 The authors of this article wish to thank Peter Post for his critical reading of an earlier draft of this paper. Moreover, special thanks go out to Go Gien Tjwan, Ing Lwan Taga-Tan, Lea Pamungkas, Maya Hian Ting Liem, Patricia Tjiook-Liem, Paul The Gwan Tjaij, Siswa Santoso, Soei Keng Que, Soei Liong Liem, and Swanny Thee for sharing their personal views, as well as for their collaboration and support. 
they have succeeded. Amongst other things, the Dutch government in 2000 apologized, and allocated the sizeable sum of 159 million euros to the Het Gebaar Foundation, to be distributed amongst its constituency of repatriates from Indonesia (Paasman 2002: 10-11; Schuurmans 2014: 34). ${ }^{2}$

However, not all have so vociferously and publicly asserted themselves. Many thousands of Indonesian Chinese, or Peranakan, also repatriated from Indonesia, but are generally not regarded to be a part of the Indisch community (Oostindie 2010: 33). Recent estimates of the number of Indonesian Chinese in the Netherlands range from 18,000 to 40,000 people (Rijkschroeff, The Gwan Tjaij, and Verlaan 2010: 155; Thio May Ling 2007: 25; Oostindie 2010: 29). Despite its size, academic interest in this group has been minimal. Dutch professor of (post-)colonial history, Gert Oostindie, has pointedly indicated why this has been the case, by giving the following reasons for more or less excluding the Indonesian Chinese from his recent publication Postcolonial Netherlands; Sixty-five years of forgetting, commemorating, silencing:

[...] this well-educated and socially successful group rarely features in debates about minorities. What is more important is that they have displayed remarkable internal cohesion, but never contrived to translate this, either symbolically or politically, into identity politics - not in Dutch society and even less so towards Indonesia, where many familial and commercial ties are maintained to this day. (Oostindie 2010: 29.)

Therefore, according to Oostindie, while most other postcolonial minorities in the Netherlands organized themselves based on their own identity, and fought with variable degrees of success for public recognition, financial compensation, as well as for a place in the national memory culture - by asking for monuments, memorial centres and commemorations -, the Indonesian Chinese didn't (Oostindie 2010: 91-97, 101-102). Why is this the case? This is the central question taken up in this paper.

In the scarce literature published about this group, this question is usually answered as follows: the Indonesian Chinese who migrated to the Netherlands were a highly educated, mostly Dutch-speaking, and relatively well-off group, which made their integration into Dutch society very successful. Moreover, they possess Chinese cultural values, such as conflict avoidance. Consequently, they never felt the need to organize themselves into pressure groups (Rijkschroeff, The Gwan Tjaij, and Verlaan 2010: 112-113, 147-149; Thio May Ling 2007: 116-117; Van Galen 1987: 144-146; Oostindie 2010: 2829). In this paper, by analysing the magazine of a Dutch Indonesian-Chinese socio-cultural association called Hua Yi Xie Shang Hui, it will be argued that the abovementioned perspective, though at first glance correct, glosses over

2350 million Dutch guilders, the equivalent of approximately 159 million euros, were allocated to Het Gebaar for distribution amongst individuals in the target group. On top of that, 35 million Dutch guilders, the equivalent of approximately 16 million euros, were granted to the foundation, to be spent on collective purposes (Stichting Het Gebaar, <http:/ /www. sawahbelanda.nl/stichting-het-gebaar/> consulted on 10-11-2016). 
possible reasons for self-silencing behaviour: most prominently, the legacies of anti-Chinese violence and discrimination in colonial and postcolonial Indonesia.

However, before taking up this matter, as academic interest in this group has been minimal, and as most of the scarce literature is written in Dutch, the scope of this article is, first of all, to give an overview of the current state of research about this community. In doing so, Indonesian Chinese immigration, integration, identity, and associations in the Netherlands will be discussed.

\section{Prologue}

The development of the colonial economy in the Dutch East Indies from the seventeenth century onwards offered opportunities for the Chinese to form a commercial middle class, situated between the Dutch rulers and the local population. Therefore, the expansion of Dutch colonial power in Indonesia went hand in hand with immigration from China, and led to the growth of an already existing Indonesian Chinese minority (Blussé and Van Luyn 2008: 133-147). Though there was a tendency amongst these Indonesian Chinese to acculturate or even assimilate into the local population, the Dutch had a vested interest in keeping the populations separated, in order to "divide and rule" (Coppel 1983: 5-24). Although the Indonesian Chinese were granted certain economic monopolies, later on, they had to live in specific quarters and obtain special passes to travel. In 1854, two different legal categories were created: "Europeans" and "Natives", which both entailed certain rights and obligations. The Indonesian Chinese were categorised as "Foreign Orientals", a category "equated" with the "Natives", but which later on more or less began to function as a separate third category (Coppel 2002a: 133-134, 140-141, 2002b: 157-168). According to the historian Charles A. Coppel, this colonial segregation-inducing policy helped to create delineations and competition between the indigenous population and the Indonesian Chinese, and thereby formed the blueprint for post-independence anti-Chinese violence and discrimination (Coppel 1983: 3, 13-14, 171). Indonesian Chinese migration to the Netherlands is closely entwined with this subject, as will be shown in the sections below. Roughly three phases in this community's migration to the Netherlands may be discerned:

1. Students, from approximately 1911 to 1940

2. "Repatriates" and "regretters", from 1945 to 1964

3. "Refugees" from the violence of $1965 / 1966^{3}$

3 Naturally, there has been Indonesian Chinese migration to the Netherlands since the late 1960s as well. However, on the basis of existing literature, it seems clear that most Indonesian Chinese migrated to the Netherlands between 1945 and the late 1960s, and information regarding the amount of Indonesian Chinese who immigrated thereafter is scarce. Nonetheless, from individual testimonies, it is known that some went to the Netherlands on account of the anti-Chinese discrimination during the New Order regime (1966-1998), as well as on account of the (anti-Chinese) riots in May 1998 (Tan 1999: 18-24; Oei Tat Ie 1999: 43-45). Moreover, Van Galen indicates that, from the 1970s onwards, there has been chain migration (Van Galen 1987: 144). Rijkschroeff, The Gwan Tjaij, and Verlaan concur, and state that during the 1980s 


\section{STUDENTS}

Until 1908, the Indonesian Chinese were more or less barred from state education by the Dutch colonial government. However, in a few cases predominantly children of wealthy individuals who were legally equated with Europeans - were Indonesian Chinese able to enrol at state schools. ${ }^{4}$ A few other options were available. Rich Indonesian Chinese could enlist the services of private Dutch schools or send their children to missionary schools (Suryadinata 1972: 52; Van Galen 1989: 20, 39; Coppel 1983: 14-15; Li Minghuan 1998: 168). ${ }^{5}$

However, given the considerable costs, a Dutch education was only possible for the privileged few. Moreover, some Indonesian Chinese parents preferred to send their children to Chinese schools: a preference which was partly fuelled by a surge in immigration from China from the 1860s onwards. Many of these new immigrants - also known as totok - were influenced by the rising tide of nationalism in China and, because their arrival was so recent, had more personal and emotional ties with their country of birth (Coppel 1983: 1-2, 9 , 11). Even amongst the Peranakan - those born and rooted in Indonesia, and oftentimes to some degree assimilated into the local population - there was a certain resinification. Therefore, from the late nineteenth century onwards, many private Chinese schools, culturally oriented towards China, were established (Peng Chia Oai 2013: 447, 452; Van Galen 1989: 21-22). ${ }^{6}$ Alarmed by these developments, the Dutch colonial government tried to drive a wedge between the Peranakan and the totok, amongst others by enacting educational reforms. In 1908, Indonesian Chinese children were permitted to enter state education - through the Hollands-Chineesche School - which allowed many more Indonesian Chinese to qualify for higher education, not only in the Dutch East Indies, but also in the Netherlands (Coppel 1983:14-15). However, partly given the considerable income requirements, in practice these were mostly Peranakan, who given their length of stay in Indonesia were on average more wealthy, and who given their rootedness were more inclined to prefer a Dutch education over a Chinese one to enhance their future opportunities in the Dutch East Indies (Rijkschroeff, The Gwan Tjaij, and Verlaan 2010: 50; Coppel 1983: 14-15; Van Galen 1989: 39-40).

As a result of this reform, between 1911 and 1940 around 900 Indonesian

several hundred Indonesian Chinese followed family members who had previously settled in the Netherlands. Moreover, they suggest that highly educated Indonesian Chinese, such as dentists, continued to emigrate to the Netherlands during the 1970s (Rijkschroeff, The Gwan Tjaij, and Verlaan 2010: 148).

4 It was possible for Indonesian Chinese to become "equated" with Europeans, though mostly for the rich (Coppel 2002a: 133-134; Laarman 2013: 35-36; Van Galen 1989: 39).

5 According to Li Minghuan, in 1863, missionary schools in Java started to accept Indonesian Chinese children.

6 In 1901, the Tiong Hoa Hwe Koan - Chinese Association - was established. This organization, with mostly Peranakan leadership, established many Chinese-language schools, with the aim of promoting Chinese culture amongst the Indonesian Chinese (Coppel 1983: 14; Suryadinata 1972: 52-53). 
Chinese pursued a higher education in the Netherlands (Van Galen 1989:39-44; Li Minghuan 1998: 169). To put this into perspective, there were approximately 1.2 million Indonesian Chinese in 1930, of whom around 29\% was literate and of whom only about 3\% could write in Dutch (Coppel 1983: 21). Clearly, this group of 900 was an elite within an elite. In 1911, these students founded their own student association in the Netherlands, called Chung Hwa Hui $(\mathrm{CHH})$, the archives of which have been analysed by Dutch historian Kees van Galen. As until 1945 most Indonesian Chinese living in the Netherlands were temporary students, and as most of them became members of $\mathrm{CHH}$, Van Galen's work offers a unique window on this community before decolonization and violence in Indonesia motivated a portion of them to permanently settle in Holland (Van Galen 1989: 40-42, 49).

The associational proceedings show that the issues these students were discussing - discrimination and the emergence of both Indonesian and Chinese nationalism - forced them to reflect upon their identity, as well as their future in the Dutch East Indies and, hypothetically, in an independent Indonesia. Were they Chinese, Indonesian or Indonesian-Chinese and should they remain visible as a distinctive cultural group or fully assimilate? According to Van Galen, most of them intended to build a future in their country of birth, went home after graduating, and were mainly concerned with their community's wellbeing. Therefore, despite nominally supporting Chinese nationalism, and occasionally viewing Indonesian nationalism with sympathy, their sense of identity remained primarily Indonesian Chinese. Consequently, as the context in the Dutch East Indies changed, they opportunistically adjusted their views. To illustrate: although Indonesian nationalism was already in development, $\mathrm{CHH}$ championed Indonesian-Chinese legal equality with Europeans, while more or less neglecting the fate of the Indonesians. However, as the Indonesian independence movement gained momentum, they switched towards arguing for a multicultural Indonesia in which all groups - Indonesians, Chinese and Europeans - would be equal. After the declaration of independence in 1945, CHH still wouldn't commit itself to supporting the new-born Indonesian state. Many of its members disagreed with this position, and left the association (Van Galen 1989: 200-201, 215-227).

Van Galen also shows that CHH students flirted extensively with Chinese nationalism during the 1920s and 1930s, for example, by celebrating Chinese festivals, organizing Chinese language education and regularly receiving the Chinese - Kuomintang - ambassador in Holland. However, according to Van Galen, these activities should not be interpreted as expressions of loyalty towards China. Instead, they were primarily fuelled by the hope that a stronger China would correspondingly enhance the marginal position of their community in Indonesia (Van Galen 1989: 203-214, 219-223). Li Minghuan makes a slightly different argument and states that these students' renewed interest in Chinese culture was caused by a severe drop in their social standing. In Indonesia, they came from wealthy families and were treated with respect, but in Holland they were seen as merely colonial subjects. Consequently, 
in order to restore their self-esteem, they took pride in Chinese culture and history (Li Minghuan 1998: 176-177). Unfortunately, both van Galen and Li Minghuan refrain from elaborating further on how these Peranakan students experienced daily life in the Netherlands. However, from individual memoires, amongst other materials, it can be established that these students did, indeed, occasionally face discrimination and that they felt as if the same colonial hierarchy that existed in Indonesia was being applied to them. For others, the cold weather and alien food will also have been reasons to long back to their country of birth (Oei Hong Kian 1998: 181-191, 273-282; Rijkschroeff, The Gwan Tjaij, and Verlaan 2010: 88-89).

It is important to understand the background of these students, as most authors on this subject agree that they, together with alumni from Dutch schools in the East Indies, formed a large proportion of the Indonesian Chinese who permanently settled in the Netherlands after 1945 (Li Minghuan 1998: 169-170; Van Galen 1987: 143-145; Rijkschroeff, The Gwan Tjaij, and Verlaan 2010: 95, 101-102; Thio May Ling 2007: 23). However, these scholars provide conflicting information with regard to many other subjects related to the immigration history of this community. For example, when it comes to calculating how many Indonesian Chinese emigrated to the Netherlands after 1945, these authors come up with wildly divergent numbers. In part, this discrepancy may be laid at the door of the Dutch Central Agency for Statistics, which registered Indonesian Chinese immigrants by their official nationality - Dutch, Indonesian or Chinese - and not as "Indonesian Chinese" (Thio May Ling 2007: 25). ${ }^{7}$ To illustrate the resulting confusion, two authors, Li Minghuan and Thio May Ling, give estimates based on interviews, which makes their numbers hard to validate (Thio May Ling 2007: 25; Li Minghuan 1998: 170). Rijkschroeff, The Gwan Tjaij, and Verlaan's numbers are based on sources which, in fact, only provide rough estimates (Rijkschroeff, The Gwan Tjaij, and Verlaan 2010: 94-95). And, finally, Van Galen partly based his numbers on outdated literature (Van Galen 1989: 43). ${ }^{8}$

\footnotetext{
7 After the formal Indonesian independence in 1949, many Indonesian Chinese could choose between these three nationalities.

8 These authors have come up with wildly divergent figures when it comes to the number of Indonesian Chinese currently living in the Netherlands, as well. Kees van Galen estimated the number of Indonesian Chinese in 1984 at 6750 people, by sampling phonebook listings of Hokkien names (Van Galen 1989: 43). Rijkschroeff, The Gwan Tjaij, and Verlaan estimated the number of Indonesian Chinese living in the Netherlands in 2010 at 18,000, within which they included the first, second, third and fourth generation (Rijkschroeff, The Gwan Tjaij, and Verlaan 2010: 155). The Gwan Tjaij stated during an interview that he and his co-authors used Van Galen's number from 1984 as a starting point and estimated the amount of Indonesian Chinese living in the Netherlands in 2010 by calculating natural growth, as well as the growth in membership of Indonesian Chinese associations and the numerous Indonesian churches. Finally, Thio May Ling mentioned in 2007 that there are between 20,000 and 40,000 Indonesian Chinese in the Netherlands, based on interviews with individual Indonesian Chinese (Thio May Ling 2007: 25). In 2010, Oostindie adopted Thio May Ling's estimation (Oostindie 2010: 29). Van Galen's methodology seems most exact, given the fact that many Chinese who migrated to Indonesia hail from areas in Fujian province where the Hokkien dialect is spoken. However, as many Indonesian Chinese changed their name to an Indonesian one during the New Order
} 
Furthermore, the same vagueness appears when these authors discuss the motivation of Indonesian Chinese for moving to Holland. Where this subject is concerned, a profound difference in approach may be discerned between two categories of authors. On the one hand, there are four authors, Thio May Ling, ${ }^{9}$ Rijkschroeff, The Gwan Tjaij, and Verlaan, ${ }^{10}$ who are members of, or connected to, Indonesian Chinese associations in the Netherlands. ${ }^{11}$ On the other hand, there are two "outsiders": Dutch historian Kees van Galen and Chinese sociologist Li Minghuan. The former category generally discusses the influence of post-independence anti-Chinese violence and discrimination in Indonesia on Indonesian Chinese migration to the Netherlands only very briefly, or in euphemistic terms, whereas the latter category more unabashedly covers this subject, as will be illustrated below.

\section{REPATRIATES, “REGRETTERS”, AND REFUGEES}

After the Dutch handed over sovereignty to the United States of Indonesia on 27 December 1949, many Indonesian Chinese could choose between the Dutch, Indonesian and Chinese nationality. ${ }^{12}$ Those who opted for the Dutch nationality were thereafter regarded as Dutch citizens and when they migrated to the Netherlands therefore, viewed as "repatriates". According to Van Galen and Li Minghuan, the Indonesian Chinese community in the Netherlands expanded to 1400 people between 1948 and 1957 (Li 1998: 169-170; Van Galen

regime (1966-1998), as many Chinese immigrants in the late nineteenth and beginning of the twentieth century came from different Chinese provinces, as some Indonesian Chinese in the Netherlands probably didn't have a phonebook listing, and because Van Galen only sampled a number of cities, this isn't a watertight method either.

9 Thio May Ling has analysed the Dutch Indonesian-Chinese association called De Vriendschap, while being a member of this association (Thio May Ling 2007: 12).

10 At the time of their joint publication titled Indonesische Chinezen in Nederland, all three authors were members of Lian Yi Hui, another Dutch Indonesian Chinese association. This book was published to celebrate this association's 25th year of existence, and is the only general work about the Dutch Indonesian Chinese community ever written (Rijkschroeff, The Gwan Tjaij, and Verlaan 2010: VII). However, one of its authors, The Gwan Tjaij, indicated during an interview that, instead of being intended as an academic study, this book was primarily meant to inform interested parties in the Netherlands about the history and the role of the Indonesian Chinese and also to pass the history and heritage of the Indonesian Chinese in the Netherlands on to succeeding generations. These authors have all published about aspects of the Indonesian Chinese community in the Netherlands, or closely related subjects, before. (An interview with Paul The Gwan Tjaij, conducted by Alexander van der Meer, telephonic, on 28-11-2016.)

11 These four authors will from now on be referred to as "Indonesian Chinese authors", by which is meant that they are all connected to, or members of, Indonesian Chinese associations in the Netherlands. Taken literally, this characterization is incorrect, as only Thio May Ling and The Gwan Tjaij are Indonesian Chinese.

12 As a result of the Dutch-Indonesian Round Table Conference in 1949, which stipulated the terms of Indonesian independence, those previously categorized as "Foreign Orientals" - which included many of the 1.2 million Indonesian Chinese - were automatically given Indonesian nationality, with, however, the possibility of applying for the Dutch nationality (Jones 2007: 83; Laarman 2013: 65). As many Indonesian Chinese were also regarded as Chinese citizens, on a ius sanguinis basis, another possibility was to become a Chinese citizen, by rejecting Indonesian nationality (Coppel 1983: 26-27; Rijkschroeff, The Gwan Tjaij, and Verlaan 2010: 95). 
1989: 43). Li Minghuan and Van Galen don't state any number for the years from 1958 to 1965, but, according to Van Galen, between 1960 and 1967, only a very small number of Peranakan arrived in the Netherlands, since migration was difficult, on account of diplomatic relations having broken down (Van Galen 1987: 144).

Rijkschroeff, The Gwan Tjaij, and Verlaan directly contradict the abovementioned information. According to them, between 1945 and 1958, around 2000 Indonesian Chinese repatriates came to the Netherlands. Thereafter, between 1959 and 1965, around 3000 so-called spijtoptanten or "regretters" followed suit (Rijkschroeff, The Gwan Tjaij, and Verlaan 2010: 94). ${ }^{13}$ In general literature about the process of repatriation from Indonesia to the Netherlands, many of those who migrated between 1958-1967 are categorized as "regretters", because they initially opted for Indonesian nationality, but after 1957 changed their minds and wished to become Dutch, thus, in a sense, regretting their original choice. However, unfortunately for them, around 1957 diplomatic relations between Indonesia and the Netherlands soured because of a territorial dispute over Dutch New Guinea, as well as the nationalization of Dutch companies which started in late 1957. Around that time, the Dutch government enacted more restrictive immigration policies, which made it more difficult for non-Dutch immigrants from Indonesia to migrate to the Netherlands, whereas previously this category had been treated with leniency. However, because of activists and pressure groups, as well as a new flow of migrants as a result of the dispute over Dutch New Guinea, the Dutch government's attitude towards these "regretters" was usually still relatively benign. ${ }^{14}$ Nonetheless, some had to stay in the Netherlands for many years illegally, in fear of being deported, or as foreigners, before being naturalized (Jones 2007: 166-172; Laarman 2013: 54-75). It is likely that many Indonesian Chinese "regretters" faced the same uncertainty. However, other than in individual memoires, there are only vague suggestions in the existing literature that this was the case (Tjwan Sie Hok 1997: 23-25; Twie 2004: 4-12; Rijkschroeff, The Gwan Tjaij, and Verlaan 2010: 112).

What motivated these "repatriates and regretters" to migrate to the Netherlands between 1945 and 1965? Rijkschroeff, The Gwan Tjaij, and Verlaan suggest that they were motivated by "affinity with the Netherlands" (Translated from Dutch; Rijkschroeff, The Gwan Tjaij, and Verlaan 2010: 94). ${ }^{15}$

13 The translation of spijtoptanten into English as "regretters" is derived from Gert Oostindie (2010: 52).

14 Because of the conflict over Dutch New Guinea, Indonesia expelled around 40,000 Dutch nationals from Indonesia between 1957 and 1959. Moreover, for many of those who had become Indonesian by choice, but who had a different ethnic background, life became much harder. Therefore, until 1967, the Dutch government had special regulations in force which allowed "regretters" - and even those who had never had the choice to opt for Dutch nationality, but who could prove a certain attachment to the Netherlands - to become Dutch. After 1967, the regular immigration policy would apply to immigrants from Indonesia (Jones 2007: 170-171; Ellemers and Vaillant 1985: 42-43).

15 Nevertheless, these three authors, in other chapters not related to migration to the Netherlands, do state that some Indonesian Chinese during this period were inclined to move 
However, this is a somewhat unconvincing explanation. From the associational archives of the $\mathrm{CHH}$ student association, it is clear that most of the pre-war Indonesian Chinese students in the Netherlands intended to build their future in Indonesia. ${ }^{16}$ Moreover, thousands came to the Netherlands between the late 1950s and 1964, many years after Indonesian independence, which attests to the same initial wish. Li Minghuan makes a different argument and states that the decision to migrate to the Netherlands during the early 1950s was made mostly on socio-economic grounds (Li Minghuan 1998: 169). Though Indonesia, indeed, faced economic troubles during the 1950s, this can only form a part of the explanation. Later on, Li slightly contradicts herself, by stating that many Indonesian Chinese who initially chose to be Indonesian were motivated to move to the Netherlands by anti-Chinese discrimination during this period (Li Minghuan 1998: 173).

It is very remarkable that the abovementioned authors do not, other than euphemistically or very briefly, include anti-Chinese violence and discrimination between 1945 and 1964 in their considerations. According to Coppel, as the Indonesian Chinese in some regards functioned as a commercial middle class, situated in between the Dutch ruling class and the indigenous population, there were three discernible socio-economic classes in Indonesia just before the decolonization, in 1939: generally, the Europeans were wealthy, the Indonesian Chinese had middle incomes, and the Indonesians were poor. In addition to the resulting socio-economic competition, the Indonesian Chinese were associated with the hated Dutch colonialism, blamed for seemingly refusing to assimilate and, finally, suspected of harbouring a foreign allegiance, because of post-independence geopolitical quarrels with China amongst other reasons, over its influence over the Indonesian Chinese minority - which altogether led to feelings of animosity between the two populations. As a result, the years between 1945 and 1964 featured periodical eruptions of anti-Chinese violence and discrimination (Coppel 1983: 11-51). This was, doubtless, a reason for some Indonesian Chinese, who initially consciously chose Indonesian nationality and intended to build a future there, to move to the Netherlands later on. ${ }^{17}$

The third wave of migration was caused by the coup attempt in Indonesia in September 1965, which led to years of intense violence and, eventually, to a regime change from Soekarno to Suharto. To what degree the Indonesian Chinese were victimized during these years is the subject of ongoing academic debate (Cribb and Coppel 2009: 447-465; Melvin 2013: 63-91). However, it is beyond question that the Indonesian Chinese community suffered intense

to Holland because of political instability and do elaborate on anti-Chinese discrimination (Rijkschroeff, The Gwan Tjaij, and Verlaan 2010: 75-79, 103).

16 To illustrate, between 1949 and 1952, more than $90 \%$ of $\mathrm{CHH}$ members chose Indonesian nationality (Van Galen 1989: 210).

17 This is confirmed by some individual Indonesian Chinese interviewed by Li Minghuan (Li Minghuan 1998: 172-173). Van Galen hints at the same reason and states that those who came to the Netherlands in the late 1950s were mostly older Peranakan who worked for Dutch companies, but left because they experienced or foresaw discrimination (Van Galen 1987: 144). 
violence - pillaging, forced displacement and rape - and that thousands were killed, which motivated many to seek refuge in the Netherlands (Cribb and Coppel 2009: 451). According to Li Minghuan, this created the biggest wave of Indonesian Chinese migration to the Netherlands: around 5000 people (Li Minghuan 1998: 170). However, once again, Rijkschroeff, The Gwan Tjaij, and Verlaan give conflicting information, and state that around 1500 Indonesian Chinese left for the Netherlands between 1966 and the beginning of the 1970s. According to the latter three authors, though many were still alumni of Dutch universities, others now had less affinity with the Netherlands, as some were born and raised in an independent Indonesia, and had studied in a different (Western) country (Rijkschroeff, The Gwan Tjaij, and Verlaan 2010: 94, 104, 147-148).

Li Minghuan and Van Galen explicitly state that these migrants came here because of intense anti-Chinese violence, and Van Galen adds that many left under harsh conditions, with no time to take more than the bare necessities or say goodbye to loved ones (Li Minghuan 1998: 169-170; Van Galen 1987: 143-144). However, according to Rijkschroeff, The Gwan Tjaij, and Verlaan, Indonesian Chinese around this time left for Holland as they "longed for peace" (Translated from Dutch; Rijkschroeff, The Gwan Tjaij, and Verlaan 2010: 95), ${ }^{18}$ and Thio May Ling states that they came here because the coup attempt led to "anti-Chinese sentiment" (Translated from Dutch; Thio May Ling 2007: 23). ${ }^{19}$ Clearly, compared to "outsiders" - Li Minghuan and Van Galen - Indonesian Chinese authors prefer to use euphemistic references to the influence of anti-Chinese violence and discrimination on Indonesian Chinese migration to the Netherlands. The next section will show that this distinction between these two groups of authors applies, though less markedly, to the integration of Indonesian Chinese in Dutch society as well.

\section{INTEGRATION AND IDENTITY IN THE NETHERLANDS}

Most authors emphasize that the integration of Indonesian Chinese into Dutch society has been remarkably successful. Rijkschroeff, The Gwan Tjaij, and Verlaan, in particular, go to great lengths to emphasize this point. They state that most Indonesian Chinese could find a job and housing by themselves, quickly adjusted to a new society, are nowadays generally content and, on average, have a high income (Rijkschroeff, The Gwan Tjaij, and Verlaan 2010: VII, 96, 104, 124, 147-151, 155). Most authors explain this phenomenon, first of all, by what Oostindie has described as a "postcolonial bonus": colonial subjects were already familiar with the Dutch language and customs

18 Though in a different chapter, not related to migration to the Netherlands, Rijkschroeff, The Gwan Tjaij, and Verlaan do elaborate on the violence which began in September 1965. They state that around 30,000 Indonesian Chinese were killed and that the anti-Chinese violence and discrimination in those years compelled many to take refuge abroad, amongst other places in the Netherlands (Rijkschroeff, The Gwan Tjaij, and Verlaan 2010: 79).

19 Thio May Ling doesn't give any estimation of the number of Indonesian Chinese who took refuge in the Netherlands because of the violence in 1965 and the years thereafter, but states that it was a "big wave" of migration (Thio May Ling 2007: 23). 
(Oostindie 2010: 21-32; Thio May Ling 2007: 23-24; Li Minghuan 1998: 170172). However, for two reasons, the Indonesian Chinese were, compared to others with a comparable postcolonial bonus, even better situated to enable a smooth integration. First of all, they were, on average, highly educated. By a rough estimation, about a third of them had an academic title, predominantly in medical and engineering disciplines (Li Minghuan 1998: 171; Rijkschroeff, The Gwan Tjaij, and Verlaan 2010: 102-103; Van Galen 1987: 145, 1989: 40-42). ${ }^{20}$ Secondly, Chinese/Confucian values, like thrift and frugality, are also credited as having contributed to societal success. Indeed, compared to the Indisch repatriates, who often initially had to be housed by the government, from individual narratives, it seems clear that the Indonesian Chinese community in the Netherlands was, to a high degree, self-reliant. In many cases, networks of friends and family already living in the Netherlands helped new arrivals out (Rijkschroeff, The Gwan Tjaij, and Verlaan 2010: 96-97). Their smooth adjustment to Dutch society compared to other immigrant groups and the resulting absence from the political agenda seem to be a source of pride for Indonesian Chinese authors (Rijkschroeff, The Gwan Tjaij, and Verlaan 2010: 139-143, 148-150, 155; Han Hwie Song 1992: 32-33).

According to Thio May Ling, the first generation of Indonesian Chinese identify strongly with the Dutch majority, as well as with their own minority (Thio May Ling 2007: 116). The second generation are even more rooted in the Netherlands. While $80 \%$ of the first generation marry and have friends predominantly within the Indonesian Chinese community, $80 \%$ of the second generation marry a non-Peranakan and two thirds of their friends are Dutch. The second generation cherishes the positive aspects of their Peranakanheritage, but they mostly identify as Dutch and rarely join Indonesian Chinese associations (Rijkschroeff, The Gwan Tjaij, and Verlaan 2010: 151-153). Therefore, some of the first generation are somewhat worried that this will lead to a loss of their unique culture and history.

Clearly, the Indonesian Chinese authors' self-representation of their communities' integration in the Netherlands is, to an extent, a "success story". Though this seems to be factually correct, it is striking that they rarely mention negative experiences with the Dutch majority. Especially bearing in mind the fact that, in the general literature about the Indisch repatriates, it is made clear that many - especially those with a coloured skin - experienced racial discrimination (Oostindie 2010: 90, 221-222). ${ }^{21}$ The Indonesian Chinese authors did not specifically address this subject. However, reading between the lines, one may suspect that this has been the case for them, too (Rijkschroeff,

20 And while in 1985, amongst the native Dutch, 1 in 1000 was a doctor, amongst Chinese in the Netherlands this was 1 in 100. Blussé and Van Luyn suggest that, as many of those doctors studied in the Netherlands, most of them will be Indonesian Chinese (Blussé and Van Luyn 2008: 204). Though many were clearly highly educated, Van Galen briefly mentions that during the 1950s there was also a less wealthy group who arrived in the Netherlands, some of whom ended up in the restaurant sector (Van Galen 1987: 145).

21 Moreover, some of the Indonesian Chinese students who studied in the Netherlands between 1911 and 1940 reported having experienced the same. 
the Gwan Tjaij, and Verlaan 2010: 141-142, 145; Thio May Ling 2007: 19-20, 30-31). Individual testimonies are less ambiguous, but still not resentful, and even adopt a conciliatory tone (Oei Hong Kian 1998: 184-185). For example, an individual who came to the Netherlands in 1949 states:

I experienced discrimination from Dutch people. They addressed me as 'Sukarno' and on the streets we were called 'nigger'. This changed over time. When we arrived [in Holland], many Dutch had probably never seen anybody who didn't have white skin before (Translated from Dutch; Rijkschroeff, The Gwan Tjaij, and $\mathrm{Wu}$ 1993: 63).

Individual testimonies, especially that of the professor of Cultural Studies, Ieng Ang, who was born in Indonesia, but in 1966, at the age of twelve, went to the Netherlands, attest to the fact that a certain form of discrimination remained evident in later decades too, amongst other ways, by being constantly categorized as "Chinese" by native Dutch (Li Minghuan 1998: 175; Ang Ien 2001: 10-11).

Regarding the complex Indonesian Chinese identity, most authors state that amongst the Peranakan in the Netherlands it is mostly made up of Dutch and Chinese elements: Chinese roots combined with a Western education and embeddedness. Identification as Indonesian is rare, but many do treasure Indonesian cultural traits out of nostalgia, and ties with family and friends living in Indonesia remain tight (Rijkschroeff, The Gwan Tjaij, and Verlaan 2010: 139-143, 151; Li Minghuan 1998: 173, 181; Thio May Ling 2007: 113115). However, most authors do mention that some of the first generation of Indonesian Chinese felt trapped between these three identities and countries and, consequently, perceived themselves as not really at home anywhere (Rijkschroeff, The Gwan Tjaij, and Verlaan 2010: 97; Thio May Ling 2007: 20, 24). In a 1998 publication, entitled Living among three walls? The Peranakan Chinese in the Netherlands, Chinese sociologist Li Minghuan covers this subject in the most detail: in Indonesia, they were regarded as Chinese, in Holland, as Asian, and in China, as foreign, too. Moreover, Li Minghuan states that, as the international status and prestige of China grew from the 1980s onwards, some felt as if their status in the Netherlands had grown similarly, which led to a certain resinification amongst the Indonesian Chinese in the Netherlands. This is an indication that the context of the Dutch society has had a great influence on the identifications of Indonesian Chinese in the Netherlands ( $\mathrm{Li}$ Minghuan 1998: 174-175, 177-181). ${ }^{22}$

The integration of Indonesian Chinese in the Netherlands has certainly

22 However, Li Minghuan's perspective became progressively more positive. While in 1998 she elaborated on the feeling of being nowhere at home, in later publications she seemed to emphasize more that many Indonesian Chinese in the Netherlands possess a transnational flexible identity which allows them to feel at home in many places. Moreover, she even suggested that Dutch Indonesian Chinese, when they emphasize their unique identity and combine the best of three cultures, have more socio-cultural capital to offer and, therefore, possess a competitive advantage over others (Li Minghuan 1999: 44-45, 2003: 228-230). 
been very smooth, though Indonesian Chinese authors represented this as a process with little friction, whereas Chinese sociologist Li Minghuan has described possible negative experiences in more detail. Regarding the complex Indonesian Chinese identity in the Netherlands, almost all authors describe Indonesian Chinese socio-cultural associations as having played a major role in creating a feeling of togetherness and a little bit of "home" in the Netherlands. How this works will be described in the next section.

\section{Associations}

In 1987, Van Galen stated that, as most Indonesian Chinese were successfully integrated and possessed a large personal network of Indonesian Chinese friends and family, there was little need for Indonesian Chinese associations. Consequently, Van Galen characterized the Indonesian Chinese community as "a village without a name" (Translated from Dutch; Van Galen 1987: 145146). However, a few years later, there were actually already four Indonesian Chinese associations: Inisiatip (1977), ${ }^{23}$ Lian Yi Hui (1983), ${ }^{24}$ Hua Yi Xie Shang Hui (1987), ${ }^{25}$ and De Vriendschap (1989). ${ }^{26}$ This was the case because many Indonesian Chinese retired around that time and had more leisure time to spend on social activities. ${ }^{27}$ Nowadays, these associations have between 100 and 500 members and share roughly the same goals, which are notably described by Thio (Rijkschroeff, The Gwan Tjaij, and Verlaan 2010: 113-115). ${ }^{28}$ Thio May Ling has studied De Vriendschap, and concludes that Indonesian Chinese become members of such associations because they enjoy spending time with people who share the same background and cultural identity. Sometimes, the members even know each other from their younger days in Indonesia (Thio May Ling 2007: 86, 88-93, 115-116). These associations, in other words, serve to create a sense of "feeling at home" in the Netherlands. Therefore, they organize socio-cultural activities which feature Chinese traditions - such as the celebration of Chinese New Year - as well as Indonesian and Western ones (Thio May Ling 2007: 70-83, 111-112).

However, it is quite remarkable that these are exclusively socio-cultural associations. Rijkschroeff, The Gwan Tjaij, and Verlaan note the same phenomenon and state that the Indonesian Chinese in the Netherlands seem to be politically inactive and are rarely members of interest groups, such as

\footnotetext{
23 Inisiatip, http://www.inisiatip.nl/default.html, consulted on 10-11-2016.

24 Lian Yi Hui, http://www.vriendenkringlianyihui.com/, consulted on 10-11-2016.

25 Hua Yi Xie Shang Hui, http:/ / www.huayixieshanghui.nl/, consulted on 10-11-2016.

26 De Vriendschap, http:/ / www.verenigingdevriendschap.nl/, consulted on 10-11-2016.

27 An interview with Patricia Tjiook-Liem, conducted by Martijn Eickhoff and Alexander van der Meer, in Amstelveen, on 02-05-2016.

28 Van Galen emphasized in 1987 that many Indonesian Chinese enjoy a large network of - mostly - other Indonesian Chinese friends and family, who regularly meet up at social occasions such as weddings (Van Galen 1987,145-146). Patricia Tjiook-Liem emphasized during an interview that the founding of these associations served to institutionalize these already existing personal ties, as well as to make new ones (An interview with Patricia Tjiook-Liem, conducted by Martijn Eickhoff and Alexander van der Meer, in Amstelveen, on 02-05-2016).
} 
labour unions and political parties (Rijkschroeff, The Gwan Tjaij, and Verlaan 2010: 112). Why is this the case? The four Indonesian Chinese authors give several explanations, which are listed below.

First of all, as a successful and relatively well-off group, the Indonesian Chinese generally didn't feel the need to organize themselves into interest groups. There were, in other words, simply no problems that needed to be addressed. However, they did feel a need to express and experience their own identity. Therefore, there are several Indonesian Chinese associations which focus on socio-cultural activities (Thio May Ling 2007:39-40, 111; Rijkschroeff, The Gwan Tjaij, and Verlaan 2010: 113, 149)..29

The second explanation has to do with Chinese/Confucian cultural values. Thio May Ling has asked members of the Dutch Indonesian Chinese association De Vriendschap, who are mostly first generation Indonesian Chinese, what they regard as their communities' most characteristic traits. Amongst the answers were: hospitality, filial piety, community spirit, family values, thrift, independence, frugality, conflict-avoidance and political aloofness (Translated from Dutch; Thio May Ling 2007: 100-107). First of all, these seem to be mostly Chinese cultural values, which could explain a certain apolitical stance. Indeed, in the general literature about the Chinese diaspora it is sometimes remarked that Chinese minorities in the West generally display apolitical behaviour (Rijkschroeff 1998: 112-115, 195-196; Freedman 2000: 2, 30-32, 130-132). Rijkschroeff, The Gwan Tjaij, and Verlaan also note that many Indonesian Chinese regard themselves as guests in the Netherlands and consequently view it as inappropriate to interfere in political and societal issues (Rijkschroeff, The Gwan Tjaij, and Verlaan 2010: 112).

Thirdly, all four Indonesian Chinese authors - though very briefly - state that historical trauma is another explanation for this phenomenon. Thio May Ling argues that the Indonesian Chinese, as a relatively well-off minority, first in the Dutch East Indies and later in Indonesia, have often experienced being scapegoated for political and social problems. Therefore, in the Netherlands, they wanted to avoid attracting too much attention, by "working hard, being independent, law-abiding, conflict-avoiding and apolitical" (Translated from Dutch; Thio May Ling 2007: 104). However, Rijkschroeff, The Gwan Tjaij, and Verlaan put forward a slightly different argument. They posit that Indonesian Chinese who left for the Netherlands between 1960 and 1975 often did so for political reasons, and that those "who had been politically active in Indonesia could have got into trouble [if they had acted likewise in the Netherlands]. Against this background, you can imagine that they weren't inclined to interfere in political issues in their new host country" (Translated from Dutch; Rijkschroeff, The Gwan Tjaij, and Verlaan 2010: 112). What are these authors

29 Rijkschroeff, The Gwan Tjaij, and Verlaan also mention a few practical reasons for being apolitical. Some Indonesian Chinese who came to the Netherlands were already middle-aged, and therefore probably less enthusiastic about realising certain political ideals. Moreover, they state that, as immigrants, after arriving, many had to first focus on practical goals, such as finding a job, securing housing and raising children (Rijkschroeff, The Gwan Tjaij, and Verlaan 2010: 112). 
somewhat vaguely and indirectly referring to?

After Indonesian independence, in the 1950s and the 1960s, many Indonesian Chinese - facing societal pressure to assimilate, as well as discrimination and occasional outbursts of violence - became politically active. There was one current amongst them which argued for integration and another which argued for assimilation. Baperki was the main organization promoting integration, ${ }^{30}$ by which they meant the right to remain a distinctive cultural group in Indonesia. Baperki became a mass organization, with 280,000 members in 1965, and, moreover, running a hundred schools, which almost exclusively catered to Indonesian-Chinese children. As Indonesian politics, including those of President Sukarno, became increasingly left-leaning in the late 1950s, Baperki followed suit and adopted the position that socialism was a way of eliminating racial tensions in Indonesia. As the violence surrounding the regime change in 1965/66 generally targeted leftist groups and (alleged) communists, Baperki and, by association, the Indonesian Chinese in general, were targeted, as well (Coppel 1983: 17, 36-37, 43-45; Tsai and Kammen 2012: 132-138).

Obviously, some of those who left for the Netherlands had been politically active in Indonesia and one may imagine they were, therefore, less inclined to do so again in the Netherlands. One of our informants called this "Baperkiphobia". ${ }^{31}$ Moreover, the fact that the Indonesian Chinese association De Vriendschap is explicitly open to non-Peranakan members is, according to Thio May Ling, directly related to historical experiences of being scapegoated in Indonesia (Thio May Ling 2007: 104, 111). Although Thio May Ling doesn't elaborate further on this point, it could very well be that this is part of an effort to avoid being once again labelled as exclusive and superior, as Baperki was perceived to be by some Indonesians..$^{32}$

To conclude, several explanations have been put forward as to why the Indonesian Chinese in the Netherlands are, by and large, apolitical and why they almost exclusively established socio-cultural associations. As has been shown in the introduction to this article, contrasting with the Indisch repatriates, the Indonesian Chinese in the Netherlands didn't organize themselves into pressure groups to campaign for compensation and acknowledgement of historical suffering. This is most likely a part of the same phenomenon, since doing so would constitute a political act.

However, all the above-mentioned economical, cultural and political explanations for this phenomenon might also be part of a collectively imposed self-image. First of all, there are other well-integrated and socioeconomic successful minorities who still organize themselves into pressure groups. Secondly, as the Indonesian Chinese are a highly Westernized group,

30 Baperki is an abbreviation of Badan Permusjawaratan Kewarganegaraan Indonesia.

31 An interview with Paul The Gwan Tjaij, conducted by Alexander van der Meer, telephonic, on 28-11-2016.

32 However, Thio May Ling doesn't mention Baperki by name. Moreover, this author states that the open character of De Vriendschap could also be explained by the high level of integration attained by Indonesian Chinese in the Netherlands (Thio May Ling 2007: 104, 118). 
Chinese/Confucian values can only be part of the explanation. And finally, the anti-Chinese violence partly induced by Indonesian Chinese political self-organization in Indonesia is now 50 years in the past. Moreover, there are Indonesian Chinese who came to the Netherlands prior to the 1960s who weren't targeted by the political violence. Therefore, it is important to trace other reasons why the Indonesian Chinese, in general, display apolitical behaviour and in this regard deviate from Indisch repatriates. In the following section, through analysis of the magazine of the Indonesian Chinese association Hua Yi Xie Shang Hui, this task will be taken up.

\section{HUA Y I MAGAZINE}

The Dutch Indonesian Chinese association Hua Yi Xie Shang Hui (HYXSH) has published a quarterly magazine, called Hua Yi Magazine, since 1988. For the purposes of the inquiry in this section, one issue per year from 1990 to 2016 has been analysed. ${ }^{33}$ This magazine is mostly read by association members. Since contributors didn't have to take the broader public into account, we assume that they could speak more freely and possibly hint at underlying explanations for Indonesian Chinese apolitical behaviour and for their deviation from other repatriates. ${ }^{34}$

First of all, what became clear is that the articles published in Hua Yi Magazine did, indeed, generally stay away from controversial or potentially painful subjects, such as the anti-Chinese violence and discrimination in colonial and postcolonial Indonesia..$^{35}$

In Table 1, the most dominant themes of articles published from 1990 to 2016 have been listed, which indicates that the vast majority of articles featured relatively harmless subjects, to do with culture, history, identity and contemporary developments across Indonesia, China, and the West. As HYXSH is a socio-cultural association, this was to be expected.

33 The archives of the National Library of the Netherlands and Leiden University only possess issues of this magazine from 1990 to 2016. The years 1988 and 1989 are missing. See the references for a list of the issues analysed in this section.

$34 \quad$ Hua Yi Magazine has an editorial board, but members of HYXSH are encouraged to publish articles too. However, especially in the earlier years, the editors wrote a large portion of the articles. Therefore, the results of this analysis could be influenced by the preferences of a few individual editors. Furthermore, the categorization applied to the articles - see Table 1 - is of course inherently subjective, but only serves to indicate a trend in the subjects of the articles. 35 Moreover, as this is an associational magazine, there are also many articles that deal with associational matters, such as announcements or reports of associational activities. 


\begin{tabular}{|l|c|c|c|c|}
\hline & Chinese & Indonesian & $\begin{array}{c}\text { Dutch/ } \\
\text { Western }\end{array}$ & $\begin{array}{c}\text { Indonesian } \\
\text { Chinese }\end{array}$ \\
\hline Culture & 130 & 13 & 25 & 9 \\
\hline History & 67 & 39 & 34 & 17 \\
\hline $\begin{array}{l}\text { Contemporary } \\
\text { developments }\end{array}$ & 18 & 8 & 8 & - \\
\hline Identity & 50 & 2 & 2 & 17 \\
\hline
\end{tabular}

Table 1. Number of articles featuring culture, history, contemporary developments and/or Indonesian Chinese identity, across China, Indonesia, the West, and those specifically about the Indonesian Chinese, in Hua Yi Magazine from 1990 to 2016.

Table 1 shows that most articles on these subjects focus on China - its history, culture and contemporary developments. Moreover, when Indonesian Chinese identity is discussed, Chinese cultural traits seem to be dominant. Furthermore, several authors express the view that China is important to the Indonesian Chinese in the Netherlands, as the international status of China affects their status in the Netherlands. As Han Hwie Song put it in 2004:

The Chinese in Indonesia regarded China [during the 1960s] as the rising star in the East which could protect her people, domestically and abroad. In the Netherlands today, our social standing is still dependent upon the status of China. (Translated from Dutch; Han Hwie Song 2004: 19-20.)

Therefore, in many articles, the rise of China since the 1980s is applauded. In some respects, this seems to be a re-assertion of the phenomenon which Van Galen and Li noted, regarding Indonesian Chinese students in the Netherlands during the 1920s and 1930s. In these decades, they similarly hoped that a strong China would correspondingly enhance their societal position (Van Galen 1989: 219-223; Li Minghuan 1998: 176-177).

There were numerous articles, especially in the first volumes, which stressed the importance of integrating in, and being loyal to, the Netherlands. Quite remarkably, several times this aspiration was explicitly presented as a lesson learned in Indonesia. For example, in 2002, Liem Tiong Biauw stated that:

We should, wherever possible, join political parties and be loyal to the Dutch people and the Dutch royal family. Otherwise, others will decide our fate [...] as we experienced [...] in 1949. We didn't help Soekarno with his nation-building, nor did we show our loyalty to the Indonesian people. (Translated from Dutch; Liem Tong Biauw 2002: 7-13.)

Moreover, Indonesian Chinese political inactivity in the Netherlands has quite often been discussed in Hua Yi Magazine. The earlier volumes regularly featured appeals to HYXSH members to become politically more active. However, most of the time, these were calls for Indonesian Chinese to pioneer 
the political organization and integration of the broader Chinese minority in the Netherlands, and to help out recent immigrants from China who weren't yet familiar with the Dutch language and customs and who, therefore, had trouble accessing the Dutch welfare state (Han Hwie Song 1990a: 19-23). ${ }^{36}$ There were no appeals for the Indonesian Chinese to organize themselves into a political pressure group, to be acknowledged and compensated for their historical suffering, nor calls to become a part of the Dutch national memory culture.

However, contrary to expectations, Dutch colonial history, including anti-Chinese colonial policies, was amply discussed and explicitly criticized. ${ }^{37}$ Indonesian Chinese political inactivity in the Netherlands is sometimes even perceived to be the direct result of these policies. In 2003, Tjwan Sie Hok stated that the socio-cultural focus of HYXSH is "to compensate for political inactivity", and that:

The fear of being politically active [...] is a colonial legacy. Previously, the colonial ruler possessed a monopoly on politics. We were expected to be obedient and not participate. Talking about trivial matters was no threat to the colonial government. (Translated from Dutch; Tjwan Sie Hok 2003: 12-14.)

Moreover, the current Indonesian Chinese status in the Netherlands has even been equated with colonial times. When, in 2004, the Indonesian Chinese were excluded from the Dutch governmental policy regarding the Chinese minority, Robert Liem rhetorically asked: "Is this another divide-and-rule policy, [this time] applied to the Chinese in the Netherlands?" (Translated from Dutch; Robert Liem 2005: 5-8). Another author, Peter B.K. Tan, denounced the state-sponsored national celebration in 2002 of the 400th birthyear of the Vereenigde Oostindische Compagnie (VOC): The Dutch East India Company, which initiated Dutch colonialism in Indonesia. He went on to explain that VOC is an abbreviation for "Vernedering, Onderdrukking en Corruptie", which translates as 'humiliation, oppression and corruption' (Translated from Dutch; Tan 2002: 27-30). Though the subjects shown in table 1 constituted the vast majority of the articles, apparently, frustration and historical grievances about Dutch colonial rule are, contrary to what could be expected based on the

\footnotetext{
36 There were 75 articles that featured the topic of integration and 27 which featured the political inactivity of the (Indonesian) Chinese in the Netherlands. Many of these writings contained calls to the Indonesian Chinese to take on a pioneering role and shoulder the responsibility for the broader Chinese minority in the Netherlands to succeed, in both respects. In particular, Han Hwie Song, who has been the chief editor of Hua Yi Magazine from 1988 until 2003 , regularly called upon HYXSH members to take on this role. However, it remains unclear if HYXSH truly engaged in closer ties with the broader Chinese minority in the Netherlands. It is telling that there are almost no articles which are able to indicate to what degree this objective had been attained. Moreover, there were progressively fewer articles featuring these topics, from roughly 2008 onwards, which suggests a loss of interest.

37 In sixteen articles, Dutch colonial policies towards the Indonesian Chinese were explicitly denounced and characterized as having caused a great deal of sorrow. There were many more articles in which the colonial era was discussed and where - especially when reading between the lines - it is possible to note a subtle feeling of indignation.
} 
literature discussed in the previous sections, still present, at least in articles by some contributors. ${ }^{38}$

The same goes for other potentially painful episodes of Indonesian Chinese history, such as the post-independence anti-Chinese violence and discrimination in Indonesia. This subject was discussed or touched upon a total of 27 times. ${ }^{39}$ On 19 occasions, it was discussed indirectly or in euphemistic terms. On six occasions, the anti-Chinese violence was addressed directly and unabashedly. And finally, on two occasions, an author partly blamed the anti-Chinese violence in Indonesia on the Indonesian Chinese themselves. An example of the latter is Peter B.K. Tan, who in 1999 recalled that, during his youth in Indonesia, many Indonesian Chinese were very rich and often had Indonesian servants, who were sometimes treated as slaves. He rhetorically asks:

Are the Chinese in Indonesia to blame for the jealousy, hate and anger [...] against the Chinese, and has this been the reason for the periodical [anti-Chinese] rioting? (Translated from Dutch; Tan 1999: 18-23.)

Sometimes the violence is discussed directly. For example, Twie MarinkelleTan in 2004 states that, in 1965:

There was a large-scale persecution of anyone suspected to have communist sympathies. The Chinese were seen by one side as collaborators with the former colonial ruler, and by the other as collaborating with communism. (Translated from Dutch; Twie 2004: 4-12.)

However, most of the time the violence and discrimination is only briefly touched upon or, indeed, ignored altogether. Twice, authors blame the fact that many Indonesian Chinese had to leave Indonesia in the 1960s and 1970s on the Cultural Revolution in China. As one of those authors, Han Hwie Song, is usually very well informed, this seems to be a conscious strategy to avoid discussing the anti-Chinese violence committed by Indonesians (Han Hwie Song 1990b: 8-10; Kho 1995: 37-41).

In general, the articles that feature non-controversial subjects - as shown in Table 1 - dwarf the number of articles in which anti-Chinese violence and discrimination are discussed. Moreover, some events in Indonesia that directly relate to historical events which Indonesian Chinese in the Netherlands could have experienced, or of which family members in Indonesia could have been

38 Sometimes, the feeling of indignation over Dutch colonial policies seems to be extrapolated. For example, one author, Wim Wei-Chun Ma, stated that the West has achieved its dominant position in the world during the colonial era in the eighteenth and nineteenth century, which "went hand in hand with unscrupulous exploitation, including slavery", which, he adds, "was abolished in the Netherlands only 150 years ago" (Translated from Dutch; Ma 2013: 34-38).

39 There were twenty articles which featured anti-Chinese violence and discrimination in postindependence Indonesia, in general. On top of that, on seven occasions, an author specifically discussed the degree to which the Indonesian Chinese were targeted during the violence in 1965/66. 
the victim, were not elaborated upon in Hua Yi Magazine. For example, the anti-Chinese riots in May 1998, when hundreds of Indonesian Chinese were killed, raped and tortured, were only once touched upon in the issue of June 1998 (Liem Tong Biauw 1998: 18-24; Suryadinata 2001: 506-507). Similarly, Hua Yi Magazine in March and June of 2016 didn't deal with the congress that was organized in April 2016 in Jakarta, at which, for the first time, survivors of the violence in 1965/1966 could publicly speak at a government-organized event. ${ }^{40}$

Why is it that Hua Yi Magazine generally steers clear of discussing the violence and discrimination in Indonesia that forced some to permanently settle in Holland? A person involved with Hua Yi Magazine, who wishes to remain anonymous, stated in an interview that amongst contributors to the magazine there exists "a common practice not to write about controversial subjects". He explained that both the Dutch colonial and the postcolonial antiChinese violence and discrimination in Indonesia are regarded as containing controversial elements. As has been shown in previous sections, scholars with ties to Indonesian Chinese associations - Rijkschroeff, The Gwan Tjaij, Verlaan and Thio May Ling - also seemed reluctant to elaborate on these subjects, compared to relative outsiders - Chinese sociologist Li Minghuan and Dutch historian Kees van Galen. What could be the reason for this being the case?

The anonymous source gave two pragmatic political reasons for the existence of this common practice amongst contributors to Hua Yi Magazine. Firstly, they don't want any negative consequences for their family and friends in Indonesia. Secondly, they don't want to criticize their host country, the Netherlands, too explicitly, as they fear that this could damage their societal status. Our source went on to explain that many - especially before receiving a permanent residence permit or naturalization - still consider themselves as guests in the Netherlands. For the same reasons, during the Cold War, they were generally wary of publicly denouncing Suharto, a Western Cold War ally. However, our source also mentioned that, as Dutch colonial history is still, to some degree, a sensitive subject in the Netherlands, they are reluctant to criticize it too publicly. These might be additional reasons to explain why the majority of the Indonesian Chinese have never organized themselves into pressure groups, nor demanded compensation for the historical suffering that prompted their migration to the Netherlands. ${ }^{41}$

\section{DUTCH NATIONAL DISCOURSE AND FAMILY TIES TO INDONESIA}

Considering the reference to colonial history as a still sensitive subject in the Netherlands, it is imperative, in these concluding remarks, to touch upon the national discourse regarding Dutch colonial history in Indonesia. According to Paul Bijl, for a long time, the Dutch saw themselves as a relatively benign

40 Joe Cochrane, "After long silence, Indonesia allows talk of anti-communist atrocities", New York Times 17 April 2016.

41 An interview conducted by Alexander van der Meer. The source wishes to remain anonymous. 
imperialist (Bijl 2012: 449). ${ }^{42}$ Bijl also stated that the Dutch, therefore, seem to suffer from aphasia when it comes to the colonial violence which they perpetrated. Consequently, "the victims of colonialism are not memorable within a national context and there is no language available to discuss them as part of Dutch history" (Bijl 2012: 458).

Building on Bijl's theory, an interesting hypothesis can be posited to explain Indonesian Chinese silence, in contrast to the other repatriates from Indonesia, who did vociferously assert themselves in a bid to become part of the Dutch national memory culture. Indisch repatriates in the Netherlands mostly drew attention to the historic circumstances surrounding their repatriation during the 1940s and 1950s - suffering during the Japanese occupation (1942-1945) as well as during the Indonesian war of independence (1945-1949), and a cold reception in the Netherlands - but, in essence, didn't challenge the abovementioned Dutch self-representation as the 'benign imperialist'. In fact, many of them were part of the colonial elite and, therefore, their narrative, to some degree, corresponded with the national one (Oostindie 2010: 131, 134, 140). ${ }^{43}$ If, on the other hand, the Indonesian Chinese draw public attention to the historic circumstances of their repatriation, this could pose a direct challenge to the Dutch national self-image, as the seeds of anti-Chinese prejudice and violence were at least partly sown by the centuries-old Dutch discriminatory, violent, and segregation-inducing colonial policies, of which many Indonesian Chinese were victims.

It may be seen, from the example of the Korean Americans, that minorities whose narrative could challenge the national discourse of their host country can silence themselves, out of fear for their societal position (Ramsay Liem 2007: 153-154, 158-162). ${ }^{44}$ Therefore, this historical background has likely been a stimulus for Indonesian Chinese in the Netherlands to engage in some form of self-silencing. However, at the same time, many of the Indonesian Chinese who migrated to the Netherlands belonged to rich families which attained their wealth by being part of the colonial system. It is plausible that this ambiguity

42 Building on Bijl's ideas, historian Chris Lorenz hypothesized that the Dutch regarded their military action during the Indonesian war of independence (1945-1949) as a humanitarian and just intervention. Information which conflicted with this self-image, such as massacres committed during this war, was actively suppressed, not least by the veterans of the said war (Lorenz 2015: 110, 128-129).

${ }^{43}$ Even more so, Oostindie posits that the Indisch repatriates to a large degree formed the Dutch national discourse by struggling "against imputations of morally wrong colonialism" (Oostindie 2010: 137). Consequently "the contemporary Dutch memory of colonialism reflects something of that distant past, but also, and perhaps more so, serves as a gesture towards the postcolonial communities that feel particularly involved with this history. Such gestures may easily come at the expense of historical consistency" (Oostindie 2010: 131).

44 Ramsay Liem illustrates such a case by discussing Korean Americans who fled to the United States because of the Korean War (1950-1953). The U.S. remembered its role in this war, amongst others, as heroically halting the expansion of communism and thereby saving South Korea. A section of the Korean refugees, however, had suffered greatly as a result of, amongst other things, American military action. Nonetheless, they kept silent, as they feared that publicly asserting their victimhood would undermine the American heroic self-image (Ramsay Liem 2007: 153-154, 158-162). 
constituted another reason to let sleeping dogs lie.

Secondly, during one interview, it was confirmed that the wellbeing of family and friends in Indonesia was a reason for some Indonesian Chinese in the Netherlands to steer clear of public discussion of controversial subjects. ${ }^{45}$ Considering the historical context of the Suharto regime (1966-1998), it is certainly plausible that Indonesian Chinese in the Netherlands have felt this concern, ${ }^{46}$ as many anti-Chinese discriminatory policies were enacted during these years. ${ }^{47}$

To conclude, following Dutch sociologist Withuis, who claims that stressing individual and collective trauma is a dominant way of generating social recognition and influence in the Netherlands, the Indonesian Chinese have, generally speaking, as a group, dissociated themselves from this dominant "trauma culture". ${ }^{48}$ It seems that most Indonesian Chinese are genuinely content with their lives in the Netherlands (Rijkschroeff, The Gwan Tjaij and Verlaan 2010: 155), and don't nurture an identity based on historical victimhood. ${ }^{49}$ However, the suggestion that there are consequently no grievances over historical injustices committed against them is erroneous. In Hua Yi Magazine, some contributors do express frustration over Dutch colonial policies, the Suharto regime and anti-Chinese violence and discrimination in Indonesia, in general. However, no pressure groups were organized to publicly address these frustrations.

The arguments presented by scholars only partly explain this phenomenon: Indonesian Chinese are successfully integrated, relatively wealthy, possess Chinese cultural values, such as conflict avoidance, and memories of the dire consequences of political self-organization in the 1950s and the early 1960s in Indonesia still haunt them. However, as has been shown in this article, this phenomenon has also at least partly been induced by the fear of speaking out,

45 An interview with Patricia Tjiook-Liem by Martijn Eickhoff and Alexander van der Meer, in Amstelveen, on 02-05-2016.

46 However, The Gwan Tjaij stated, during an interview, that this phenomenon applies mostly to the first generation of Indonesian Chinese who migrated to the Netherlands and hardly applies, at all, to members of the second generation, who were born in Holland (An interview with Paul The Gwan Tjaij, conducted by Alexander van der Meer, telephonic, on 28-11-2016).

47 Finally, one author in Hua Yi Magazine, Tjwan Sie Hok, mentioned several times that the Dutch secret service had spied on some of them during the Cold War. He suggested that this was the case because some Indonesian Chinese had, indeed, had leftist sympathies (Tjwan Sie Hok 1997: 23-26). Moreover, he referred to links between Western secret services and the Suharto regime (Tjwan Sie Hok 2000: 30-32). Though it is unlikely that many Indonesian Chinese in the Netherlands were under the scrutiny of the secret services, for some, the mere possibility that this might have been the case could have been a reason for not publicly asserting themselves. 48 However, during an interview The Gwan Tjaij mentioned that he knows quite a few Indonesian Chinese who had applied for compensation from the Dutch government trough the Het Gebaar Foundation in 2001. However, this claim was negotiated by an Indisch repatriate foundation, centered around the main grievances of the Indisch community. Therefore, it can be concluded that, although some Indonesian Chinese individuals joined this claim, this in fact didn't constitute an instance of Indonesian Chinese identity politics (an interview with Paul The Gwan Tjaij, conducted by Alexander van der Meer, telephonic, on 28-11-2016).

49 An interview with Soei Keng Que, conducted by Alexander van der Meer, telephonic, on 08-11-2016. 
on account of the long arm of the Indonesian government, as well as Dutch discomfort about acknowledging the violent and discriminatory elements of its own colonial past. Moreover, as the Indonesian Chinese also, to some degree, cooperated with the Dutch colonial rulers, they can, in a sense, be viewed as partners and victims simultaneously. This ambiguity could have hindered the development of an identity as "victim" and thereby further complicated the construction of a narrative that would serve to publicly address historical injustices committed against them. Consequently, the Indonesian Chinese in the Netherlands are not only a living legacy of colonial and postcolonial violence - as many were directly or indirectly compelled by those reasons to move to the Netherlands - but are, at the same time, bound by these legacies.

\section{REFERENCES}

Ang Ien. 2001. On not speaking Chinese; Living between Asia and the West. London: Routledge.

Bijl, Paul. 2012. "Colonial memory and forgetting in the Netherlands and Indonesia", Journal of Genocide Research 14(3-4): 441-461.

Blussé, Leonard and Floris-Jan van Luyn. 2008. China en de Nederlanders; Geschiedenis van de Nederlands-Chinese betrekkingen 1600-2007. Zutphen: Walburg Pers.

Coppel, Charles A. 1983. Indonesian Chinese in crisis. Singapore: Oxford University Press.

Coppel, Charles A. 2002a. “The Indonesian Chinese: 'Foreign Orientals', Netherlands subjects, and Indonesian citizens", in: M. Barry Hooker (ed.), Law and the Chinese in Southeast Asia, pp. 131-149. Singapore: Seng Lee Press. Coppel, Charles A. 2002b. "The Indonesian Chinese as 'Foreign Orientals' in the Netherlands Indies", in: Charles A. Coppel (ed.), Studying ethnic Chinese in Indonesia, pp. 157-168. Singapore: Singapore Society of Asian Studies.

Cribb, Robert and Charles A. Coppel. 2009. "A genocide that never was; Explaining the myth of anti-Chinese massacres in Indonesia, 1965-66", Journal of Genocide Research 11(4): 447-465.

Ellemers, J.E. and R.E.F. Vaillant. 1985. Indische Nederlanders en gerepatrieerden. Muiderberg: Coutinho.

Freedman, Amy L. 2000. Political participation and ethnic minorities; Chinese overseas in Malaysia, Indonesia, and the United States. London: Routledge.

Galen, Kees van. 1987. "Dorp zonder naam; De Chinezen uit Indonesië", in: Gregor Benton and Hans Vermeulen (eds), De Chinezen, pp. 132-147. Muiderberg: Coutinho.

Galen, Kees van. 1989. Geschiedenis van de Chung Hwa Hui (1911-1962); IndoChinese studenten en Peranakan politiek in Nederland. Amsterdam.

Han Hwie Song. 1990a. "Drie sociaal-politieke en culturele stromingen van de Chinese gemeenschap in Nederland", Hиа Yi Magazine 3(1): 19-23.

Han Hwie Song. 1990b. “Deng-Jie, lantaarnfestival”, Hua Yi Magazine 3(1): 8-10. Han Hwie Song. 1992. "Een antwoord voor mr. Tan Eng-Swie", Hua Yi Magazine 5(3): 32-36. 
Han Hwie Song. 2004. “De totok- en de baba- en nyonyacultuur gezien vanuit mijn achtergrond" , Hua Yi Magazine 17(4): 13-19

Jones, Guno. 2007. Tussen onderdanen, rijksgenoten en Nederlanders. Amsterdam: Rozenberg Publishers.

Kho, O.T. 1995. “Pinangsia, Glodok, Pantjoran, Pasar Baru, Pasar Senen, Mester", Hua Yi Magazine 8(2-3): 37-42.

Laarman, Charlotte. 2013. Oude onbekenden; Het publieke en politieke debat over postkoloniale migranten, 1945-2005. Hilversum: Uitgeverij Verloren.

Li Minghuan. 1998. "Living among three walls; The Peranakan Chinese in the Netherlands", in: Elizabeth Sinn (ed.), The last half century of Chinese overseas, pp. 167-183. Hong Kong: Hong Kong University Press.

Li Minghuan. 1999. We need two worlds; Chinese immigrant associations in a Western society. Amsterdam: Amsterdam University Press.

Li Minghuan. 2003. "From 'sons of the yellow emperor' to 'children of the Indonesian soil'; Studying Peranakan Chinese based on the Batavia Kong Koan archives", Journal of Southeast Asian Studies 34(2): 215-230.

Liem, Ramsay. 2007. "Silencing historical trauma; the politics and psychology of memory and voice", Peace and Conflict; Journal of Peace Psychology 13(2): 153-174.

Liem, Robert. 2005. "Hua yi in het jaar van de aap; Een terugblik", Hua Yi Magazine 18(1): 5-8.

Liem Tong Biauw. 1998. “The last of the Peranakans”, Hua Yi Magazine 11(2): 18-24.

Liem Tong Biauw. 2002. "Niet alle Chinezen zijn Chinezen", Hua Yi Magazine 15(2): 7-14.

Lorenz, Chris. 2015. “De Nederlandse koloniale herinnering en de universele mensenrechten; De casus Rawagede", Tijdschrift voor Geschiedenis 128(1): 109-130.

Ma, Wim Wei Chun. 2013. “Op weg naar één wereld?”, Hua Yi Magazine 26(2): 34-38.

Melvin, Jess. 2013. "Why not genocide? Anti-Chinese violence in Aceh, 19651966", Journal of Current Southeast Asian Affairs 32(3): 63-91.

Oei Hong Kian. 1998. Kind van het land; Peranakan-Chinezen in drie culturen. Rotterdam: Indonet.

Oei Tat Ie. 1999. “Impressies en contrasten”, Hua Yi Magazine 12(3): 43-45.

Oostindie, Gert. 2010. Postcolonial Netherlands; Sixty-five years of forgetting, commemorating, silencing. Amsterdam: Bert Bakker.

Paasman, Bert. 2002. “Wandelen onder de palmen; De morele actualiteit van het koloniale verleden". [Inaugural Lecture, Universiteit van Amsterdam.]

Peng Chia Oai. 2013. "Chinese education in Southeast Asia”, in: Tan CheeBeng (ed.), Routledge handbook of the Chinese diaspora, pp 446-458. London: Routledge.

Rijkschroeff, B.R. 1998. Etnisch ondernemerschap; De Chinese horecasector in Nederland en in de Verenigde Staten van Amerika. Cappelle a/d IJssel: Labyrinth Publication. 
Rijkschroeff, B.R., P. The Gwan Tjaij, and S.M. Wu. 1993. Bij leven en welzijn; De positie van oudere Chinezen en oudere Indische Nederlanders vergeleken. Cappelle a/d IJssel: Labyrinth Publication.

Rijkschroeff, Boudie, Paul The Gwan Tjaij and Antoon Verlaan. 2010. Indonesische Chinezen in Nederland. Amsterdam: SWP.

Schuurmans, Paulien. 2014. "Tussen wal en schip; Ervaringen van Indische Nederlanders bij de repatriëring", Skript Historisch Tijdschrift 25(1): 32-45. Suryadinata, Leo. 1972. "Indonesian Chinese education; Past and present", Indonesia 14: 49-71.

Suryadinata, Leo. 2001. “Chinese politics in post-Suharto's Indonesia; Beyond the ethnic approach", Asian Survey 41(3): 502-524.

Tan, Peter B.K. 1999. "Bezinning en reformatie; Een terug- en vooruitblik voor Chinese Indonesiërs", Hua Yi Magazine 12(3): 18-23.

Tan, Peter B.K. 2002. “Niet praten, maar werken”, Hua Yi Magazine 15(2): 27-30. Thio May Ling. 2007. Genoegens van wederzijds ((h)er)kennen; Identiteitsbeleving van Peranakan Chinezen bij de vereniging De Vriendschap. Amsterdam: Rozenberg Publishers.

Tjwan Sie Hok. 1997. “Uit BVD dossier”, Hua Yi Magazine 10(1): 23-25.

Tjwan Sie Hok. 2000. "Soeharto manipulator geen mastermind G30S", Hua Yi Magazine 13(4): 30-32.

Tjwan Sie Hok. 2003. "De Arabische ziekte“, Hua Yi Magazine 16(3): 12-15.

Tsai, Yen-ling and Douglas Kammen. 2012. "Anti-communist violence and the ethnic Chinese in Medan, North Sumatra", in: Douglas Kammen and Katharine McGregor (eds), The contours of mass violence in Indonesia, 196568, pp 131-155. Singapore: NUS Press.

Twie, Marinkelle-Tan. 2004. "De roots van de eerste generatie peranakan Chinezen in Nederland; Waarom zijn ze hier en waar komen ze vandaan", Hua Yi Magazine 17(4): 4-12.

Withuis, Jolande. 2002. Erkenning; Van oorlogstrauma naar klaagcultuur. Amsterdam: De Bezige Bij.

Hua Yi MAGAZINE (SELECTION OF ISSUES ANALYSED FOR THIS ARTICLE) 1990.3(1). 1991. 4(2). 1992. 5(3). 1993. 6(4). 1994. 7(1). 1995. 8(2-3). 1996. 9(4). 1997. 10(1). 1998. 11(2). 1999. 12(3). 2000. 13(4). 2001. 14(1). 2002. 15(2). 
2003. 16(3).

2004. 17(4).

2005. 18(1).

2006. 19(2).

2007. 20(3).

2008. 21(4).

2009. 22(2).

2010. 23(3).

2011. 24(4).

2012. 25(1).

2013. 26(2).

2014. 27(3).

2015. 28(2).

2016. 29(2).

INTERVIEWS

Anonymous source.

Patricia Tjiook-Liem, conducted by Martijn Eickhoff and Alexander van der Meer, in Amstelveen, on 02-05-2016.

Paul The Gwan Tjaij, conducted by Alexander van der Meer, telephonic, on 28-11-2016.

Soei Keng Que, conducted by Alexander van der Meer, telephonic, on 0811-2016. 